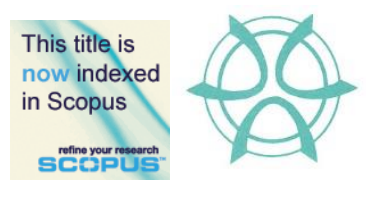

PLANNING MALAYSIA:

Journal of the Malaysian Institute of Planners

VOLUME 16 ISSUE 4 (2018), Page 208 - 219

\title{
THE PHYSICAL CHARACTERISTICS OF THE ISLAMIC GARDEN AND THE IMPORTANCE OF THE CONCEPT IN MALAYSIA
}

\author{
Haza Hanurhaza Md Jani ${ }^{1}$ \& Nor Zalina Harun² \\ ${ }^{1}$ Kulliyyah of Architecture and Environmental Design \\ INTERNATIONAL ISLAMIC UNIVERSITY MALAYSIA \\ ${ }^{2}$ Institute of the Malay World and Civilisation \\ UNIVERSITI KEBANGSAAN MALAYSIA
}

\begin{abstract}
Islamic garden is a traditional garden concept that is significantly related to the history of the Muslim civilization. The first establishment of the concept was in the 7th century through the formation of the Persian Garden. Presently, the idea of the Islamic garden is beginning to be overlooked as the contemporary garden design is becoming a current trend. The situation has given a negative impact towards the implementation of the traditional garden concept. This study is conducted to identify the physical characteristics of the Islamic garden. The first objective is to determine the chronology of the Islamic garden design and, second, to categorize the physical characteristics of the garden according to the level of its importance. Three types of methods are embedded in the study, which are the document analysis, site study, and semi-structured interviews. The method of analysing the data is using the Atlas.ti and Microsoft Excel software. The result gathered are categorized into two important aspects: (1) the movement of the Islamic garden concept in response to the history of the Muslim civilization and (2) the list of the physical characteristic of the Islamic garden. The result is triangulated as to develop an understanding on the list of the significant physical characteristics of the Islamic garden that can be embedded as part of a garden concept in Malaysia. Above and beyond that, the result includes a viewpoint from the National Landscape Department (NLD) on the direction of a garden in Malaysia pertaining to the Islamic garden concept. The input from the session is perceived as necessary as to further develop an understanding of the current level of adaptation of the Islamic garden concept, particularly in Malaysia.
\end{abstract}

Keywords: garden, Islamic garden, physical characteristics, Malaysia 


\section{INTRODUCTION}

Islamic garden is recognized as the earthly garden of paradise (Brookes, 1987; Ahmadi, 2014). The inspiration for the garden is according to the interpretation of a garden in paradise based on the Al-Quran (Kausar, 2006). The description is beautiful and overwhelms resulting the designers to create a garden as a resemblance of the depiction. In the Al-Quran, garden is explained in a manner that water and plants are the important elements shaping the garden (Ahmadi, 2014). In the early 5th century, during the pre-Islamic era, Persia is located in the deserted area and hostile environment where the presence of water was limited (Tajaddini, 2008; Ruggles, 2012). The arrival of Islam in the 6th century brought along the new insight on the description of paradise by the Al-Quran. The Persian garden was perceived as the result of the arrival of Islam in the country (Sanchez, 2008). The garden is regarded as the first establishment of the Islamic garden throughout the history of the Muslim civilization. It is also acknowledged as the basis for the following Islamic garden that occurs after the 7th century, such as the Andalusian garden and the Mughal garden (Wescoat, 2011).

However, the adaptation of the Islamic garden concept has been decreasing since the early the 21 st century. There are several factors which have influenced the decreasing number of the Islamic garden. Among them are the interference of the modern movement and the deficiency in term of the physical elements of the Islamic garden as well as the lack of appreciation towards the traditional garden design (Brookes, 1987). Therefore, this study is conducted to identify the physical characteristics of the Islamic garden based on three prominent gardens, which are the Persian garden, the Andalusian garden and the Mughal garden. Two objectives are outlined in the study. The first one is to identify the chronology of the Islamic garden design. The second objective is to categorize the physical characteristics of the garden according to the level of its importance. The initiative to identify and document the physical characteristics is perceived as a step to protect the Muslim legacy from disappearing and being forgotten.

\section{LITERATURE REVIEW}

Faghih and Sadegby (2012) regarded the Islamic garden as a valuable historical and cultural background that is closely related to the Muslim civilization. The influences of the garden reaches the entire part of the world after the 19th century, such as in the Royal Pavilion in Brighton, England (Petruccioli, 1998). The acceptance and the adaptation of the concept were widely recognized by the society. Due to the significant cultural influences, there are surviving Islamic gardens that are being preserved and listed on the UNESCO World Heritage Site. The garden is protected by the organization so as to preserve the original condition and physical characteristics, which defined the Islamic garden, from declining. The Alcazar palaces and the Alhambra in Spain are among the listed 
Haza Hanurhaza Md Jani \& Nor Zalina Harun

The Physical Characteristics of The Islamic Garden and The Importance of The Concept in Malaysia

Islamic gardens under the World Heritage Site (Rostami, Lamit, Khoshnava, Rostami, \& Rosley, 2015; Md.Jani, Harun, Mansor, \& Zen, 2018).

The early discovery of the Islamic garden occurs after the arrival of Islam and the establishment of the first Islamic city-state, Medina in the 6th century. According to Wescoat (2011), the Persian garden is perceived as the first creation of the Islamic garden and it is considered as the earthy garden of paradise. Brookes (1987) supports the idea as he stated the initial idea of the Persian garden is related to the interpretation of a garden in the paradise as described by the $\mathrm{Al}$ Quran. In the Al-Quran, a true believer is promised with the highest reward and the eternal happiness in the paradise (MacDougall \& Ettinghausen, 1976). The description of the paradise is described with the beautiful garden decorated with abundant types of edible trees with an unlimited resource of the flowing water (Brookes, 1987). The interpretation of the garden is portrayed exquisitely, resulting designers to materialize the imaginary garden into a garden design. Therefore, the Islamic garden is known as the "Earthly Garden of Paradise" (Kausar, 2006; Faghih \& Sadegby, 2012; Zakaria \& Ramli, 2016).

Numerous researchers have discussed on the prominent Islamic garden such as the Taj Mahal in the Mughal civilization, the Alhambra during the Andalusian period and the well-known Fin Garden in Persia (Menocal, Scheindlin, \& Sells, 2000; Koch, 2005; Faghih \& Sadegby, 2012). These gardens have become the basis as well as the garden of reference concerning the Islamic garden (Rostami et al., 2014). Throughout the chronology of the evolution of Islamic garden, it is discovered that the physical characteristics of the garden design play a big role in shaping the garden design. However, a study conducted by Farahani, Motamed and Jamei (2016) discovered that there are several modifications and improvement that have been made to expand the functions of the garden as well as its utilizations. Although the characteristics may have changed or altered through the evolution, nonetheless, the Islamic garden's philosophy remains the same. The garden evolves around similar philosophy, which is the earthly garden of paradise (Ruggles, 2003; Ahmadi, 2014).

Islamic garden is closely associated with the symbol of paradise as the word garden is often cited and described in the Quran. "Garden underneath which rivers flow" is cited more than thirty times in the Al-Quran (Itani, 2014). Hence, water is viewed as an ideal element for and Islamic garden. Other research indicates that the basic physical characteristics of the Mughal garden are defined in term of the layout and the elements. Kausar (2006) describes the basic layout of a typical Mughal garden is designed in a geometrical pattern and the chaharbagh or better known as the fourfold design. It is the straightforward layout adapted from the traditional Persian garden design (Koch, 2005). The layout of the garden in square or rectangular form following the chaharbagh garden design. The spaces are divided into a smaller pattern and it can reach up to sixteen from the original four-fold design (MacDougall \& Ettinghausen, 1976; 
PLANNING MALAYSIA:

Journal of the Malaysia Institute of Planners (2018)

Brookes, 1987, Nadiem, 2005). The design elements consist of horizontal planes, levels of the topography are being modified into terraces and arranged according to the hierarchy, symmetry, linear paths, and the trees are planted to create vista and avenues (Faghih \& Sadegby, 2012; Mahdavinejad, Rostam, \& Mahdavi, 2013; Morris et al., 2013).

Tajaddini (2008), and Asif, Utaberta, Othuman Mydin and Mohd Yunos (2015) studied the characteristics of the Persian garden and discovered that the focal point of an Islamic garden is the presence of the water elements. It is inevitable as water is an important element in the design of an Islamic garden as being mentioned numerously in the Al-Quran (Kausar, 2006). The running water is arranged in the form of canals with stones or brick. Meanwhile, the water cascades are flowing over carved chutes to create a better impact on the waterfalls to compliment as a decorative usage of the water element (Ruggles, 2003). Ansari (2011) states that it is often encountered that the Islamic garden is taking the advantage of flowing water from the water bodies such as mountain and directed the running water through a qanat or channel into the city. The water flows and channelling into a garden for functional and aesthetic usages (Koch, 1997; Bagherirad et al., 2014). Other than that, Tajaddini (2008) emphasizes that trees are significant in the Islamic garden design for the purpose of shade and shadow. It is observed as the highlighted characteristics for the Islamic garden. In relation to the statement, Wescoat (2011) findings on the Mughal garden revealed that trees such as plane and cypress are planted in rows along the garden to emphasis the garden avenue and the tall trees are planted to provide shadows and filter the sandy air as well as to cooling the temperature.

\section{METHODOLOGY}

This study adopted three types of method, namely the document analysis, site study and semi-structured interview. The document analysis focused on collecting and categorizing data relating to the Islamic garden and the physical characteristics. A checklist on the characteristic was produced and it was viewed as a guideline to measure the Islamic garden concept. The characteristics were classified under three garden orders which were the watering order, the planting order and the lodgement (man-made) order. The orders were observed as the key elements in measuring the physical characteristics of the Islamic garden. Each of the garden orders emphasised on the variables related to the Islamic garden design.

The checklist was designed as a reference for the site studies, which was conducted in the Andalusian gardens. Among the prominent Islamic gardens throughout the history, the Andalusian gardens are perceived as the most successful design of the Islamic garden. The gardens were also developed during the peak of the Muslim civilization. Therefore, three gardens from the Andalusian gardens were selected as the site studies. The selected gardens were the Alcazar 
Haza Hanurhaza Md Jani \& Nor Zalina Harun

The Physical Characteristics of The Islamic Garden and The Importance of The Concept in Malaysia

Palace in Seville (S1), the Alcazar Palace in Cordoba (S2) and the Alhambra in Granada (S3).

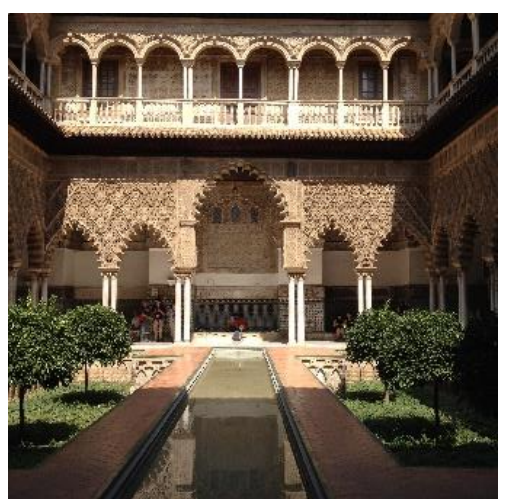

Alcazar Palace in Seville (S1)

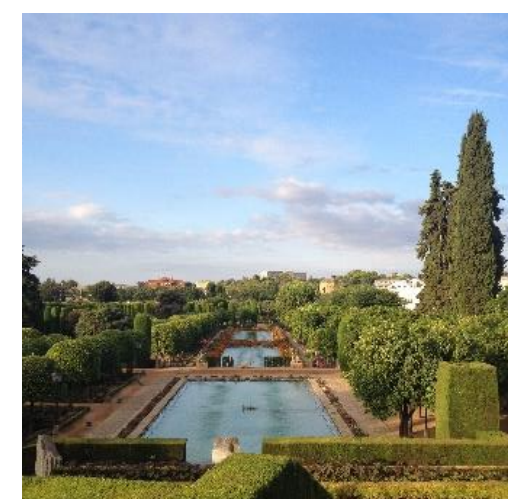

Alcazar Palace in Cordoba (S2)

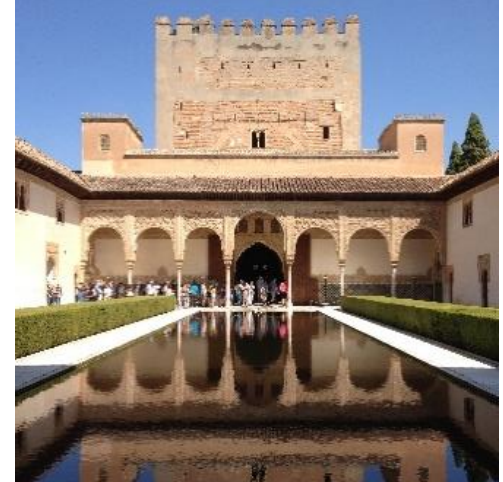

Alhambra in Granada (S3)

Figure 1: Site studies S1, S2 and S3

These gardens were selected based on the history, background and cultural influences in response to the Islamic garden. The checklist was referred to measure and observe the existing Islamic garden design as well as to crossreference the theoretical and the empirical findings. The outcome of the study assisted in strengthening the checklist and highlighted on the important variables related to the Islamic garden. The checklist is observed as an important step to measure the original characteristic of the Islamic garden before the idea can be materialized into a garden design. A semi-structured interview was conducted with the National Landscape Department (NLD) to discover the level of the implementation of the Islamic garden in Malaysia, the importance of the adaptation of the concept in the country as well as the relevance of the implementation of the concept in the context of a multicultural society. Three 
interviewees from the department were interviewed for the purpose of this study under the code NLD1, NLD2 and NLD3.

\section{RESULT AND DISCUSSIONS}

This section highlights on two aspects. The movement of the Islamic garden throughout the history of the Muslim civilization and the physical characteristics of the garden based on three garden's orders which are the watering order, the planting order and the lodgment order. The result is supported by the semistructured interview conducted with the National Landscape Department. The interview highlighted on three important factors, namely the level of the implementation of the Islamic garden in Malaysia, the importance of the adaptation of the concept in the country and the relevance of the implementation of the concept in the context of a multicultural society. The result and discussion are presented below.

\section{Movement of Islamic Garden Concept in Response to the History of Muslim Civilization}

In tracing back the history of Islamic garden based on the chronology of the Muslim civilization, it has been discovered that the movement of the Islamic garden began in the 7th century through the establishment of the Persian garden. Following the movement, there were another two notable Islamic gardens that play a significant role in shaping the garden design, namely the Andalusian garden and the Mughal garden. The Islamic garden received the acknowledgement by the European culture in the 19th century. Later on, the concept has been well accepted by many designers all over the region. However, the downfall of the Islamic garden began in the early 20th century. The modern movement has overshadowed most of the traditional garden concept and Islamic garden was one of the affected gardens. The contemporary garden design has started to become a must trend and its concept has been increasingly implemented in the garden for the purpose of simplicity and elegance. The chronology of the movement of Islamic garden concept is presented in Figure 2. 
Haza Hanurhaza Md Jani \& Nor Zalina Harun

The Physical Characteristics of The Islamic Garden and The Importance of The Concept in Malaysia

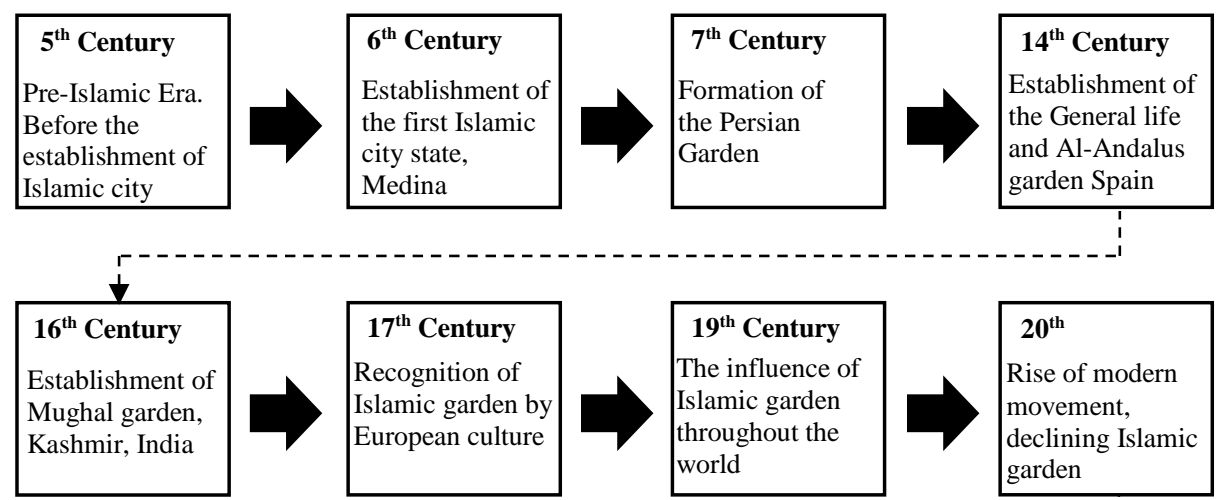

Figure 2: The movement of Islamic garden concept

\section{List of Physical Characteristic of Islamic Garden According to the Garden's Order}

Based on the document analysis and the site studies, it has been discovered that the physical characteristics of Islamic garden can be categorized into three garden orders. Each of the order is emphasizing on the garden's arrangement. The result gathered from the data collection regarding the variables of the garden's orders is presented in Table 1, Table 2 and Table 3.

Table 1: Water arrangement

\begin{tabular}{|c|c|c|}
\hline Arrangement & Aspect & Variables \\
\hline \multirow{14}{*}{$\begin{array}{l}\text { Water } \\
\text { Arrangement }\end{array}$} & \multirow{5}{*}{$\begin{array}{l}\text { Layout of } \\
\text { Water } \\
\text { Flows }\end{array}$} & Central axis according to the chaharbagh layout \\
\hline & & Central axis have a channel or broad pool \\
\hline & & Creates a cross plan section of four divisions \\
\hline & & Occupied the primary and secondary axes \\
\hline & & Water appears sunken \\
\hline & \multirow{6}{*}{$\begin{array}{l}\text { Water } \\
\text { Course }\end{array}$} & Irrigated in a straight line \\
\hline & & Direction depends on the topography \\
\hline & & Followed various angular paths \\
\hline & & Turns 90 degree angle \\
\hline & & Flows in geometrically regular \\
\hline & & Influence plants arrangement and path circular \\
\hline & \multirow[t]{3}{*}{ Colour } & The water reflects the colour of the canal bed \\
\hline & & Turquoises and blues ceramic as canal bed \\
\hline & & $\begin{array}{l}\text { If the bed has a brighter colour, its reflection becomes } \\
\text { secondary }\end{array}$ \\
\hline
\end{tabular}

Table 2: Plants arrangement

\begin{tabular}{lll}
\hline Arrangement & Aspect & Variables \\
\hline Planting & $\begin{array}{l}\text { Layout of } \\
\text { arrangement } \\
\text { planting } \\
\text { design }\end{array}$ & Follows the watercourse and pathways pattern \\
\cline { 3 - 3 } & & Symmetrical patterns and linear form \\
\cline { 3 - 3 } & & Figure-ground, continuity, closure and similarity \\
\cline { 3 - 3 } & & Planting zone serves a specific purpose \\
\hline
\end{tabular}


PLANNING MALAYSIA:

Journal of the Malaysia Institute of Planners (2018)

\begin{tabular}{|c|c|c|}
\hline & & Orchard in the centre or inner section \\
\hline & & Geometric pattern in rectangular or star-shape \\
\hline & & Plant's boundary made with various materials \\
\hline & & Varied selection of plant at the edge of the plant bed \\
\hline & Tree & Planted in a row along the main axis \\
\hline & & Arranged in a row, an $\mathrm{X}$ or diamond pattern \\
\hline & & Based on height, function and zoning layers \\
\hline & & Straight, rectilinear or bilaterally symmetrical form \\
\hline & & Trees are planted closely to one another \\
\hline & & Shady trees planted beside watercourses and paths \\
\hline & Shrub & Massing shrubs as hedges and framing \\
\hline & & Linearity or formally arranged form \\
\hline & & High shrubs to enhance lines and direct view \\
\hline & & Flowering plants close to pathways or building \\
\hline & & Small or low shrubs selected for the courtyard \\
\hline & Ground- & Parallel to the water channel \\
\hline & cover & Linear, symmetrical or irregular form \\
\hline & Vine & Vines occupy the pavilion or wall \\
\hline & & Vibrant and colourful flowering vines \\
\hline & Aquatic & Floating lotus decorate the water bodies \\
\hline & & No specific pattern of aquatic plants \\
\hline & & Table 3: Lodgement Arrangement \\
\hline Arrangement & Aspect & Variables \\
\hline Lodgement & Layout of & Chaharbagh influence the lodgement arrangement \\
\hline arrangement & lodgement & Pavilion is at the centre or at the end \\
\hline & design & Pathways are perpendicular to water channel \\
\hline & Building & At central axis or a distance from the entrance \\
\hline & & Optional to have secondary buildings \\
\hline & & Location of the Secondary buildings is optional \\
\hline & & Secondary buildings follow geometrical pattern \\
\hline & Entrance & Direct/bend entrance at main axis or middle line \\
\hline & & Bent entrances offer a delayed viewing \\
\hline & & Bent entrances have a porous curtain wall \\
\hline & & Porous curtain wall between garden and entrance \\
\hline & & Clear view between main entrance and building \\
\hline & & One or a few other entrances alongside it \\
\hline & & $\begin{array}{l}\text { Secondary entrances are for the other building and services } \\
\text { (trash removal) }\end{array}$ \\
\hline & & Secondary entrance(s) at the side of the garden \\
\hline & Pathways & Water channel at the central axis shaped pathway \\
\hline & & Main pathway does not occupy the central axis \\
\hline & & Perpendicular from the wall of the entrance \\
\hline & & Main pathways are cut off by the main building \\
\hline & & Consist of even number $(2,4,6 \ldots)$ \\
\hline & & Main paths are parallel to each other \\
\hline & & Turn 90 degree angle to change course \\
\hline & & On and around the inner face of the wall \\
\hline & & Stairs and ramps follow the layout of pathways \\
\hline
\end{tabular}


Haza Hanurhaza Md Jani \& Nor Zalina Harun

The Physical Characteristics of The Islamic Garden and The Importance of The Concept in Malaysia

\begin{tabular}{ll}
\hline Pavilion & Secondary pathways parallel to the main pathways \\
\cline { 2 - 2 } Layout, pattern and design are geometry \\
\hline & $\begin{array}{l}\text { Located at the intersections or the end of the north-south axis } \\
\text { Its centre point reflects the meaning of the social status }\end{array}$ \\
\hline As a point of observation \\
\hline Perpendicular to the watercourse and walkways \\
\hline
\end{tabular}

Table 1, Table 2 and Table 3 show the results gathered from the movement of the Islamic garden through the history and the data gathered from the site studies. The findings emphasize on the arrangement of the physical characteristics in a garden space. Based on the result, it has been discovered that the elementary principles of the Islamic garden consist of the water, plants and lodgement order. The arrangement of the order is observed as a significant step to measure and implement the garden concept into a garden design. Presently, the idea of Islamic garden is undervalued and overlooked. According to the National Landscape Department (NLD), the situation is occurring because there are no proper guidelines that act as references to implement Islamic garden concept in Malaysia. Limited knowledge and understanding of the concept are the main reasons leading to the issues. The result gathered from the semi-structured interview is presented in Table 4.

Table 4: Interview results with the National Landscape Department

\begin{tabular}{|c|c|c|}
\hline Questions & NLD & Findings \\
\hline \multirow[t]{3}{*}{$\begin{array}{l}\text { The level of } \\
\text { the } \\
\text { implementation } \\
\text { of the Islamic } \\
\text { garden in } \\
\text { Malaysia }\end{array}$} & NLD1 & $\begin{array}{l}\text { The Islamic garden concept is rarely being used in Malaysia. There } \\
\text { is a need for a proper guideline to indicate Islamic garden concept. } \\
\text { Presently, there is no guideline that the NLD could select as a } \\
\text { reference. So it is difficult for the government and the private sector } \\
\text { to apply the Islamic concept. Therefore, we still lack in terms of } \\
\text { implementation of this concept in our country. }\end{array}$ \\
\hline & NLD2 & $\begin{array}{l}\text { Islamic garden is not a very strong concept in our country. At this } \\
\text { time, the NLD do not emphasize on this concept to be used in the } \\
\text { development. However, in our policy, the department do give some } \\
\text { emphasis on the identity and image of a garden design. }\end{array}$ \\
\hline & NLD3 & $\begin{array}{l}\text { There are several attempts or efforts done by the department. } \\
\text { However, the implementation of the concept is very limited. }\end{array}$ \\
\hline \multirow[t]{3}{*}{$\begin{array}{l}\text { The } \\
\text { importance of } \\
\text { the adaptation } \\
\text { of the concept } \\
\text { in the country }\end{array}$} & NLD1 & $\begin{array}{l}\text { Concerning on the importance of Islamic garden, it is indeed } \\
\text { important. The Department appreciate any current research } \\
\text { concerning the topic of Islamic garden and we felt it it necessary for } \\
\text { the development of gardens in Malaysia. }\end{array}$ \\
\hline & NLD2 & $\begin{array}{l}\text { In Malaysia, Islam is the official religion and the country is a multi- } \\
\text { ethnic society. It is considered important and significant to apply the } \\
\text { Islamic garden, but a consideration in terms of the need and } \\
\text { appropriateness should be taken into consideration. }\end{array}$ \\
\hline & NLD3 & $\begin{array}{l}\text { The idea of Islamic garden is important as it is related to the Muslim } \\
\text { civilization. However, consideration in terms of the suitability and } \\
\text { possibility towards the usage of the concept must be taken into }\end{array}$ \\
\hline
\end{tabular}


PLANNING MALAYSIA:

Journal of the Malaysia Institute of Planners (2018)

\begin{tabular}{lll}
\hline & \multicolumn{1}{c}{$\begin{array}{l}\text { consideration. Then only Islamic garden design can be implemented } \\
\text { in our country. }\end{array}$} \\
\hline $\begin{array}{l}\text { The relevance } \\
\text { of the } \\
\text { implementation } \\
\text { of the concept } \\
\text { in the context } \\
\text { of a } \\
\text { multicultural } \\
\text { society }\end{array}$ & \begin{tabular}{l} 
Islamic garden is perceived as a relevant garden approach. \\
Concerning the values of Islamic garden, it is not impossible that \\
the concept could be accepted by the society. The Japanese, \\
Balinese and English gardens are well accepted by the society. \\
\cline { 2 - 4 }
\end{tabular} & $\begin{array}{l}\text { Hence, it is possible that the idea of Islamic garden could be } \\
\text { considered too. }\end{array}$ \\
\cline { 2 - 4 } & NLD2 $\begin{array}{l}\text { As a multicultural society, the possibility and the relevancy of } \\
\text { Islamic garden concept would seem a bit challenging. However, } \\
\text { with proper knowledge and understanding on the importance of the } \\
\text { garden, the implementation of the concept is not impossible. }\end{array}$ \\
\cline { 2 - 4 } & NLD3 $\begin{array}{l}\text { NLD encourage garden design with a distinctive identity. If the } \\
\text { garden happened to adapt Islamic garden concept, there is no } \\
\text { restriction by the department and we would allowe the } \\
\text { implementation of the concept. }\end{array}$ \\
\hline *NLD 1, NLD 2 and NLD 3 are the representatives from National Landscape Department
\end{tabular}

Based on the semi-structured interview conducted with the National Landscape Department, it is discovered that Islamic garden is not a strong concept in the country. The emphasis on Islamic garden in the National Landscape Policies is relatively general. The Department acknowledged on the needs for Malaysia to adopt the concept. However, there has been inadequate understanding, insufficient knowledge and no proper guidelines to assist the government as well as the private sector in the implementation of the concept. Despite the poor appreciation of Islamic garden, it is observed by the Department that the awareness regarding the concept is starting to be taken into consideration by the government themselves and the private sector, as well as the society. Nevertheless, a proper guideline to outline the physical characteristics and arrangement of the garden spaces is viewed as an important aspect to be considered for the future reference in response to Islamic garden implementation in Malaysia.

\section{CONCLUSION}

This study emphasizes on the physical characteristics of Islamic garden in reference to the prominent gardens such as the Persian garden, the Andalusian garden and the Mughal garden. It highlights on the relevance of implementing the concept from Asian point of views, namely Malaysia. In general, Islamic garden has received less attention by the society nowadays due to the popularity of the modern garden movement. In Malaysia, the absence of a proper guideline is one of the main reasons the lack of implementation of the concept. Other than that, limited understanding and inadequate knowledge of the Islamic garden also contribute to the current situation. Therefore, to embrace the legacy of the Muslim civilization, this study is conducted to highlight the physical characteristic of Islamic garden. The identification of the characteristics is regarded as important 
Haza Hanurhaza Md Jani \& Nor Zalina Harun

The Physical Characteristics of The Islamic Garden and The Importance of The Concept in Malaysia

to encourage Islamic garden concept implementation. Based on the findings, it has been discovered that water and plants are the main characteristics that are significantly related to the Islamic garden. The two elements are repeatedly mentioned in the Al-Quran. The findings also provide a guiding principle which includes the garden elements as well as the arrangement in response to Islamic garden concept. It is hoped that the checklist could be viewed as a reference concerning the implementation of Islamic garden in Malaysia.

\section{ACKNOWLEDGEMENT}

The authors would like to express their sincere gratitude to the Ministry of Higher Education Malaysia (MOHE) support of this research. This research is funded by the Fundamental Research Grant Scheme (FRGS), research project code FRGS 15-193-0434.

\section{REFERENCES}

Ahmadi, M. (2014). Exploring the impact of religious and pre-Islamic Persian Gardens in the creation of Chahar Bagh Avenue, Isfahan. In M. Hoxley, \& A. Crabbe (Eds), CADBE Doctoral Student Conference: 2014 Proceedings (pp. 4-17). Nottingham: Nottingham Trent University.

Ansari, N. (2011). Origin of Islamic garden. Retrieved July 5, 2015, from http://www.academia.edu/1861364/Origin_of_Islamic_Gardens

Asif, N., Utaberta, N., Othuman Mydin, M. A., \& Mohd Yunos, M. Y. (2015). Redefining Islamic garden: Comparative analysis of approaches, ideas and design framework. Jurnal Teknologi, 75(9), 77-81.

Bagherirad, E., Ahmad, N., Amirkhani, M., Abdullah, M., Mesdaghi, M., \& Kabudi, A. (2014). Seasonal habitat use of Persian Gazelles (Gazella subgutturosa subgutturosa) based on vegetation parameters at Golestan National Park, Iran. Arid Land Research and Management, 28(4), 464-484.

Brookes, J. (1987). Gardens of paradise: The history and design of the great Islamic gardens. New York: New Amsterdam.

Faghih, N., \& Sadeghy, A. (2012). Persian gardens and landscapes. Architectural Design, 82(3), 38-51.

Farahani, L. M., Motamed, B., \& Jamei, E. (2016). Persian gardens: Meaning, symbolism, and design. Landscape Online LO, 1-19.

Itani, T. (2014). The Quran. Dallas: ClearQuran.

Kausar, S. (2005). Meaning of Mughal landscape. 10th International Seminar on Cultural Landscapes in the 21 st Century. April 11-15, Newcastle UK.

Koch, E. (2005). The Taj Mahal: Architecture, symbolism, and urban significance. Muqarnas Online, 22(1), 128-149.

MacDougall, E. B., \& Ettinghausen, R. (1976). The Islamic garden. Washington: Dumbarton Oaks, Trustees for Harvard University.

Mahdavinejad, M., Rostam, N. G., \& Mahdavi, S. (2013). The role of the Gestalt Theory in understanding persian architectural masterpieces. Case study: Fin Garden of Kashan. International Journal of Management and Sustainability, 2(1), 1-13. 
Md.Jani, H. H., Harun, N. Z., Mansor, M., \& Zen, I. (2018) A review on the values of the Islamic garden in response to a garden design in Malaysia. In B. McLellan (Ed.), Sustainable future for human security (pp. 251-261). Singapore: Springer.

Menocal, M. R., Scheindlin, R. P., \& Sells, M. A. (2000). The literature of Al-Andalus. New York: Cambridge University Press.

Morris, K. I., Chan, A., Morris, K. J. K., Ooi, M. C. G., Oozeer, M. Y., Abakr, Y. A., ... \& Al-Qrimli, H. F. (2017). Impact of urbanization level on the interactions of urban area, the urban climate, and human thermal comfort. Applied Geography, $79,50-72$.

Nadiem, I. H. (2005). Gardens of Mughal Lahore. Lahore: Sang-e-Meel Publications.

Petruccioli, A. (1998). Rethinking the Islamic garden. In J. Coppock, \& J. Miller (Eds.), Transformation of Middle Eastern natural environment: Legacies and lessons (pp. 349-363). New Haven: Yale University Press.

Ruggles, F. (2003). The Framed Landscape in Islamic Spain and Mughal India. In B. J. Day (Ed.), The garden: Myth, meaning, and metaphor (pp. 21-50). Windsor, Ont.: Humanities Research Group, University of Windsor.

Ruggles, F. (2012). The earliest surviving Islamic garden: The courtyard of the Great Mosque of Cordoba. Manzar: The Iranian Scientific Journal of Landscape, 4(19), 95.

Rostami, R., Lamit, H., Khoshnava, S. M., Rostami, R., \& Rosley, M. S. F. (2015). Sustainable Cities and the Contribution of Historical Urban Green Soaces: A Case Study of Historical Persian Gardens. Sustainability, 7(10), 13290-13316.

Sanchez, G. (2008). Utility and aesthetics in the gardens of An-Andalus: Species with multiple uses. In P. Dendle, \& A. Touwaide (Eds.), Health and healing from the medieval garden (pp. 205-207). Woodbridge: The Boydell Press.

Tajaddini, L. (2008, June). Investigating the characteristics of Persian gardens: Taking a close look at Mahan Shah Zadeh garden. Geo-Environment and Landscape Evolution 2008. June 16-18, 2008. The New Forest, UK.

Wescoat, J. L. (2011). Architecture in Islamic arts: Treasures of the Aga Khan Museum. Geneva: Aga Khan Trust for Culture.

Zakaria, R. M. A., \& Ramli, Z. (2016). Significance of garden design decoration in Islamic bookbinding. Islamic Quarterly, 60(4), 529-545.

Received: $1^{\text {st }}$ June 2018. Accepted: $1^{\text {st }}$ December 2018 